\title{
SPATIAL ABILITY, 3D MODELING AND STYLES OF THINKING IN RELATION TO BRAIN HEMISPHERE DOMINANCE
}

\author{
Andrej Šafhalter \\ Primary School Anice Černejeve Makole, Slovenia \\ E-mail: andrej.safhalter@os-makole.si
}

Srečko Glodež, Karin Bakračevič Vukman

University of Maribor, Maribor, Slovenia

E-mail: srecko.glodez@uni-mb.si, karin.bakracevic@um.si

\begin{abstract}
The progress of neuroscience and the understanding of children's styles of thinking are opening up new teaching styles that take into account differences in individual cognitive perception. Students can be classified into three distinctive perceptive types, according to the pronounced activity of one cerebral hemisphere in their thinking and information processing: left-hemisphere, right-hemisphere, and integrative type that does not exhibit a considerable dominance of one particular hemisphere.

The purpose of the research was to establish differences in the $3 D$ modeling encouraged progression of spatial ability between the left-hemisphere, right-hemisphere and integrative types of students.

Computerized 3D modeling employed during technical extra-curricular activity in lower secondary school (grades 6 to 9) may affect the spatial ability of students, which according to other studies, appears to be predominantly connected with the right brain hemisphere. Research was conducted among a variety of lower secondary school students across Slovenia aged 11 - 15 years. Data on spatial ability and its development was collected using a hybrid spatial intelligence test conducted on two separate occasions, while assessment of the learning perception type of students - depending on hemispheric dominance was obtained using a self-evaluation questionnaire. The 3D modeling of technical objects and objects drawn in orthographic or isometric projection was done with the software Trimble SketchUp.
\end{abstract}

Key words: cognitive development, $3 D$ modeling, hemispheric dominance, spatial ability.

\section{Introduction}

The great progress in neuroscience and neuropedagogy in recent times and the subsequent better knowledge of the human brain, particularly in the age of growing up and schooling, has led to possibilities of new and different methods of teaching. The way a child thinks can now be better understood and different methods can be used to achieve one's goals. Furthermore, the development of each individual is taken into consideration.

Noel Entwistle (Entwistle, 1981) tried to prove a connection between the way an individual processes information and the brain hemisphericity. The visual learning style is said to be connected with integrative learning and such individuals are more inclined towards divergent thinking; whereas verbal learning is said to be more analytical and inclined towards convergent thought processes. What is characteristic of divergent thinking is the scattering of ideas, thinking in several directions and directing thoughts away from the mainstream. Creative persons think in such a way. In the case of convergent thinking, there is an aspiration towards a solution 
Andrej ŠAFHALTER, Srečko GLODEŽ, Karin BAKRAČEVIČ VUKMAN. Spatial Ability, 3D Modeling and Styles of Thinking in Relation to Brain Hemisphere Dominance

PROBLEMS

OF EDUCATION

IN THE $21^{\text {st }}$ CENTURY

Volume 54, 2013

anticipated in advance. It is more about moving to and fro between different levels of thinking. Persons using this style of thinking may be intolerant of other-minded people. As stated by Entwistle, "persons with an integrative learning style are more prone towards divergent thinking, which means that they are using broader conceptual categories and are more willing to accept the content and analytical connections between notions. They may also be more impulsive. Persons with a sequential learning style often employ more convergent thought processes, are more cautious, conservative, analytical, and often reject certain connections because they are relying on narrow categories." (Marentič-Požarnik, Magajna and Peklaj, 1995, p. 171)

Whereas divergent thinking is characteristic of the right-hemispheric type, convergent thinking is mostly found in the left-hemispheric types. The division into right-hemispheric and left-hemispheric learning styles was already mentioned by Reynolds, Kaltsounis and Torrance (Reynolds, Kaltsounis and Torrance, 1979). Today, in addition to the two mentioned categories, there are also students of an integrative type, whose hemispheric dominance is not particularly expressed.

Persons with highly-developed spatial intelligence, which is merely one type of intelligence according to Gardner, have good spatial ability. The author of multiple intelligences Howard Gardner (Gardner, 2010) claims that intelligence tests measure only the linguistic and logical-mathematical intelligence. In addition to the above mentioned intelligences, Gardner defines a spatial, musical, bodily-kinesthetic, interpersonal and intrapersonal intelligence. What is important for spatial intelligence is the ability to correctly perceive the visual world, carry out transformations of initial perceptions and recreate aspects of visual experience. Spatial intelligence could also be called visual, as it is closely connected with the observation of the visual world. However, it does not depend solely on the visual world, for it can also develop in a blind person. In this type of intelligence it is very important how one perceives an object from another angle or what the object would look like turned upside down.

As described in the work of Barbara Meister Vitale (Meister Vitale, 2004), there are different explanations as to the specialization of the brain hemispheres. According to one explanation, the brain hemispheres are said to develop symmetrically until the age of four. Specialization is said to occur only after age four. Each side of the brain has its forte in different cognitive functions. Specialization is said to be concluded by age five. According to another explanation, hemispheric domination, lateralization and functional specialization are said to occur after birth during specific periods. Individual specialized functions are thus said to be activated whenever a child is exposed to specific stimuli from the environment. Lateralization is not obvious until the corpus callosum between the hemispheres is fully developed, which occurs between the ages five and six. Specialization and lateralization are said to be fully completed around age nine. The third theory claims that language functions develop at birth, whereas the specialization of other functions develops gradually and is concluded during puberty.

As regards the very understanding of space and spatial relations, the Swiss psychologist Piaget spoke of four stages: sensory-motor ( $0-2$ years), preoperational (2-7 years), concrete operational stage (7-11 years) and formal operational stage (11-15 years). (Labinowicz, 2010) At this stage, i.e. the formal operational stage, the understanding of the notions of space continues to develop to more complex geometric systems and spatial relations. Piaget claimed that perceptive development took place according to different types of geometry, either as sequential, topological, projective or Euclidean. At this stage the child understands the notion of abstract space. He/she sees his/her viewpoint as merely one of the possible ones and is able to connect the world of formal notions with propositional statements and deduce the meaning of different forms of conversions. In addition, the child is able to present an object using abstract mental operations with the ability of integrating elements. (Labinowicz, 2010) The explanation of the perception of space at this stage was supplemented by neo-Piagetian theorists. 
Thus Andreas Demetriou (Demetriou and Raftopoulos, 2004) expanded the imaginative-

PROBLEMS

OF EDUCATION

IN THE $21^{\text {st }}$ CENTURY

Volume 54, 2013

spatial perception of children at this age to the following stages:

- 11 - 12 years: capable of perceiving abstract notions of images and objects,

- 13 - 14: show originality in imagining known and unknown images and objects,

- 15 - 16: capable of mental manipulation in forming images of pictures and objects and shaping aesthetical criteria.

\section{Methodology of Research}

\section{General Research Characteristics}

The purpose of the research was determining the influence of 3D modeling on differences in the development of spatial ability of left-hemispheric, right-hemispheric and integrative types of students. It was conducted during the technical extra-curricular activity of 3D modeling, which was carried out with the free computer tool Trimble Sketchup. With the mentioned software tool the students modeled objects on the basis of orthographic or isometric projection and various objects from their surroundings (furniture, buildings, vehicles, technical aids and the like). Sketchup enables rotating an object or displaying it from different viewing angles. The spatial ability of students was tested twice; before the start and after the implementation of the 3D modeling activity. The entire student sample was also tested for the style of learning and thinking according to the hemisphericity of the brain.

\section{Sample of Research}

The research was conducted between 2011 and 2013 in eight different lower secondary schools in Slovenia on a sample of 90 students, 62 males (68.9 \%) and 28 females (31,1\%), aged 11 to 15, who belong to the formal operational stage by Piaget's classification as regards their understanding of space and spatial relations. Since 3D modeling is not a part of the compulsory activity in the curricula and syllabi of Slovenian lower secondary schools, i.e. it is not being carried out as a compulsory subject, the sample was chosen on the basis of applications for the extra-curricular activity, which was being carried out at the schools participating in the research.

\section{Instrument and Procedures}

Two measuring instruments were used for the needs of this experiment, namely a self-assessment questionnaire "A Children Form of Your Style of Learning and Thinking", form A for children, and a hybrid spatial ability test. The self-assessment questionnaire, intended for determining the style of learning and thinking according to the hemisphericity of the brain, contained 36 sets of different statements about the manner in which one thinks about things and feelings. Each set contains three different answers of which a student chooses one. Each of these three statements is characteristic of a style of thinking, i.e. whether the left or right brain hemisphere is dominant. The third choice presents the manner for which the dominance of either of the hemispheres cannot be precisely defined; such individuals are called the integrative type.

The hybrid spatial ability test consisted of several spatial ability tests, among others the so-called PSVT:R (Purdue Spatial Visualization Test: Rotations), MRT (Mental Rotation Test), DAT:SR (Differential Aptitude Test: Space Relations), and PRT (Picture Rotation Test) tests. These tests include images of objects that are virtually displayed three-dimensionally in a two- 
Andrej ŠAFHALTER, Srečko GLODEŽ, Karin BAKRAČEVIČ VUKMAN. Spatial Ability, 3D Modeling and Styles of Thinking in Relation to Brain Hemisphere Dominance

OF EDUCATION

IN THE $21^{\text {st }}$ CENTURY Volume 54, 2013

dimensional medium. They mainly require rotating geometric shapes and objects, with four choices given, of which only one is correct. The tested subject must determine which object or geometric shape is identical to a specific object or geometric shape. The hybrid test consisted of two sets. The first set, set A, contained tasks for determining the identicalness of two geometric shapes, of which one was rotated. In the second part, set B, students had to carry out mental spatial manipulation in order to successfully solve the task. These tasks were mostly about determining the suitability of an object with regard to its grid or about determining what an object looks like when rotated.

\section{Data Analysis}

At the end of each test "A Children Form of Your Style of Learning and Thinking" points were collected according to the individual answers. The total of all points was 36; a deviation of left- or right-hemispheric answers shows a tendency of the dominance of one of the hemispheres when thinking about things and feelings.

The students were able to collect 16 points at the hybrid spatial ability test, both at the initial and final test. The part of the test which contained the rotation of geometric shapes had a total of 8 points; the same amount of points could be collected in the tasks of virtual threedimensional mental manipulation.

The statistical data analysis was carried out with the SPSS program; the two tests used were the paired samples t-test and the analysis of variance test; descriptive methods were also applied.

\section{Results of Research}

A test of the arithmetic means and characteristics of the differences for Pre-test and Posttest was conducted with a paired samples t-test. The results are shown in Table 1, Table 2 and Table 3 . The null hypothesis: $\mathrm{H}_{0}: \mu_{\text {Pre }}=\mu_{\text {Post }}$ was proposed.

Table 1. Differences in the Mean Values of Pre-test and Post-test.

\begin{tabular}{lllll}
\hline & Mean & N & Std. Deviation & Std. Error Mean \\
\hline Pre-test & 7.6778 & 90 & 2.59571 & 0.27361 \\
Post-test & 10.3556 & 90 & 2.78161 & 0.29321 \\
\hline
\end{tabular}

Table 2. Paired Samples Correlations.

\begin{tabular}{llll}
\hline & N & Correlation & Sig. \\
\hline Pre-test \& Post-test & 90 & 0.625 & 0.000 \\
\hline
\end{tabular}

Table 3. Paired Samples Test.

\begin{tabular}{|c|c|c|c|c|c|c|c|c|}
\hline & \multicolumn{5}{|c|}{ Paired Differences } & \multirow[t]{3}{*}{$t$} & \multirow[t]{3}{*}{ df } & \multirow{3}{*}{$\begin{array}{l}\text { Sig. } \\
\text { (2-tailed) }\end{array}$} \\
\hline & \multirow[t]{2}{*}{ Mean } & \multirow[t]{2}{*}{$\begin{array}{l}\text { Std. Devia- } \\
\text { tion }\end{array}$} & \multirow[t]{2}{*}{$\begin{array}{l}\text { Std. Error } \\
\text { Mean }\end{array}$} & \multicolumn{2}{|c|}{$\begin{array}{l}95 \% \text { Confidence Interval of } \\
\text { the Difference }\end{array}$} & & & \\
\hline & & & & Lower & Upper & & & \\
\hline $\begin{array}{l}\text { Pre-test } \\
\text { Post-test }\end{array}$ & -2.67778 & 2.33598 & 0.24623 & -3.16704 & -2.18852 & -10.875 & 89 & 0.000 \\
\hline
\end{tabular}


As Sig (2-tailed) amounts to less than 0.05, the null hypothesis is rejected; it is deduced

PROBLEMS

OF EDUCATION

IN THE $21^{\text {st }}$ CENTURY

Volume 54, 2013

that the differences between both tests were not created randomly but were the result of the influence of training.

On the basis of the self-assessment questionnaire, students were categorized into different learning styles, relating to the style of thinking. There were 17 (18.9\%) of students with a left-hemispheric style, 44 (48.9\%) with an integrative style and 29 (32.2\%) with a righthemispheric style.

Table 4. Share of Individual Learning Styles, Obtained by the Self-Assessment Questionnaire "A Children Form of Your Style of Learning and Thinking".

\begin{tabular}{lllll}
\hline & Frequency & Percent & Valid Percent & Cumulative Percent \\
\hline Left-hemispheric & 17 & 18.9 & 18.9 & 18.9 \\
Integrative & 44 & 48.9 & 48.9 & 67.8 \\
Right-hemispheric & 29 & 32.2 & 32.2 & 100.0 \\
\hline Total & $\mathbf{9 0}$ & $\mathbf{1 0 0 . 0}$ & $\mathbf{1 0 0 . 0}$ & \\
\hline
\end{tabular}

Table 5 shows the results obtained by the analysis of variance test. At the first spatial ability test the students with the left-hemispheric style obtained 7.06 points on average, those with the integrative style 7.68 and those with the right-hemispheric style 8.03 points. At the second test the students with the left-hemispheric style obtained 10.18 points on average, those with the integrative style 10.61 and the right-hemispheric ones 10.07 points. When comparing the progress in the spatial ability of students with individual learning styles, there are no statistically significant differences among the left-hemispheric, integrative and right-hemispheric students (Table 5 and Table 6). However, when comparing merely the arithmetic means, the greatest progress ( +3.12 points) can be seen in the left-hemispheric students; the integrative students made slightly less progress ( +2.93 points) and the right-hemispheric students made the least progress ( +2.07 points), which is shown in Figure 1.

Table 5. Results of the Analysis of Variance Test.

\begin{tabular}{|c|c|c|c|c|c|c|c|c|c|}
\hline & & \multirow[t]{2}{*}{$\mathbf{N}$} & \multirow[t]{2}{*}{ Mean } & \multirow[t]{2}{*}{$\begin{array}{l}\text { Std. De- } \\
\text { viation }\end{array}$} & \multirow[t]{2}{*}{ Std. Error } & \multicolumn{2}{|c|}{$\begin{array}{l}95 \% \text { Confidence } \\
\text { Interval for Mean }\end{array}$} & \multirow[t]{2}{*}{ Min } & \multirow[t]{2}{*}{ Max } \\
\hline & & & & & & $\begin{array}{l}\text { Lower } \\
\text { Bound }\end{array}$ & $\begin{array}{l}\text { Upper } \\
\text { Bound }\end{array}$ & & \\
\hline \multirow{4}{*}{ Pre-test } & Left-hemispheric & 17 & 7.0588 & 2.56102 & 0.62114 & 5.7421 & 8.3756 & 4.00 & 12.00 \\
\hline & Integrative & 44 & 7.6818 & 2.41866 & 0.36463 & 6.9465 & 8.4172 & 3.00 & 13.00 \\
\hline & Right-hemispheric & 29 & 8.0345 & 2.88448 & 0.53563 & 6.9373 & 9.1317 & 4.00 & 15.00 \\
\hline & Total & 90 & 7.6778 & 2.59571 & 0.27361 & 7.1341 & 8.2214 & 3.00 & 15.00 \\
\hline \multirow{4}{*}{ Post-test } & Left-hemispheric & 17 & 10.1765 & 2.67477 & 0.64873 & 8.8012 & 11.5517 & 5.00 & 13.00 \\
\hline & Integrative & 44 & 10.6136 & 2.77209 & 0.41791 & 9.7708 & 11.4564 & 5.00 & 16.00 \\
\hline & Right-hemispheric & 29 & 10.0690 & 2.91463 & 0.54123 & 8.9603 & 11.1776 & 5.00 & 16.00 \\
\hline & Total & 90 & 10.3556 & 2.78161 & 0.29321 & 9.7730 & 10.9382 & 5.00 & 16.00 \\
\hline \multirow{4}{*}{ Difference } & Left-hemispheric & 17 & 3.1176 & 2.28808 & 0.55494 & 1.9412 & 4.2941 & -1.00 & 7.00 \\
\hline & Integrative & 44 & 2.9318 & 2.36641 & 0.35675 & 2.2124 & 3.6513 & -2.00 & 8.00 \\
\hline & Right-hemispheric & 29 & 2.0690 & 2.20277 & 0.40905 & 1.2311 & 2.9069 & -3.00 & 7.00 \\
\hline & Total & 90 & 2.6889 & 2.31577 & 0.24410 & 2.2039 & 3.1739 & -3.00 & 8.00 \\
\hline
\end{tabular}


Andrej ŠAFHALTER, Srečko GLODEŽ, Karin BAKRAČEVIČ VUKMAN. Spatial Ability, 3D Modeling and Styles of Thinking in Relation to Brain Hemisphere Dominance

OF EDUCATION

IN THE $21^{\text {st }}$ CENTURY

Volume 54, 2013

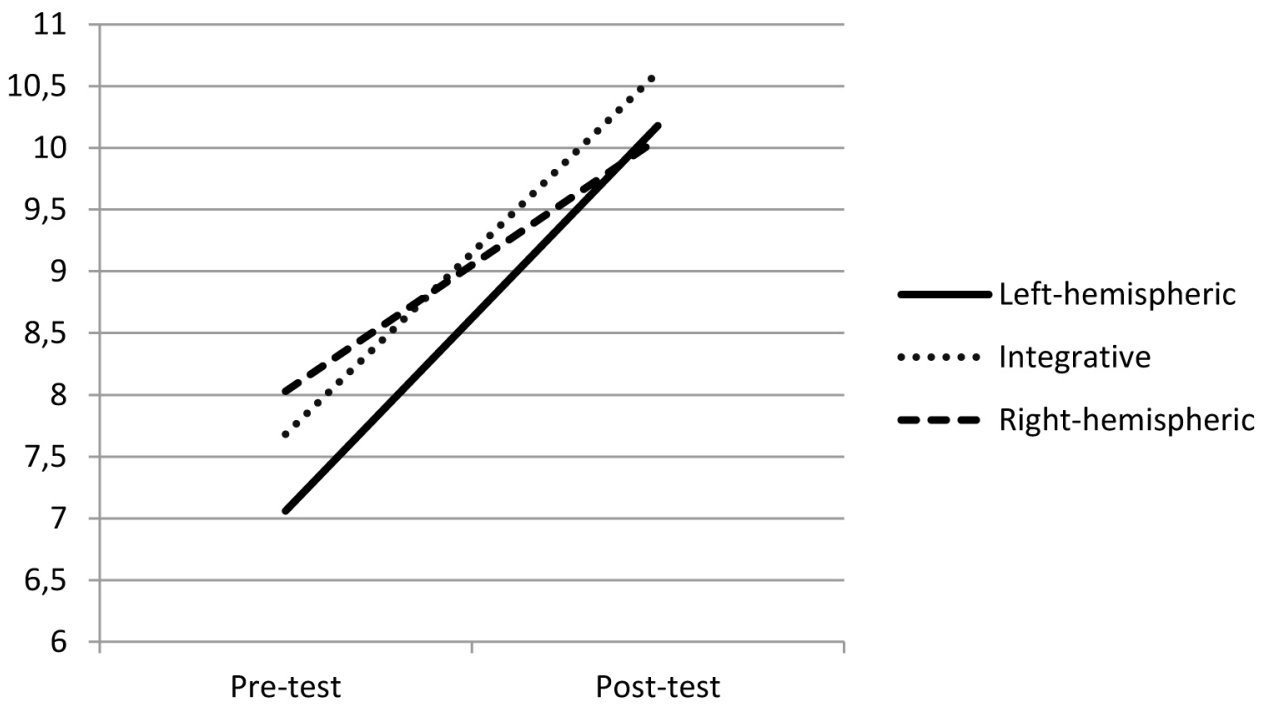

Figure 1: Differences in the Means of Points Obtained Pre-test and Post-test.

Table 6 shows the testing of the validity of the test at the level of the population. The table clearly shows that in Pre-test and Post-test, as well as in the testing of the differences between both mentioned tests, the significance level is higher than 0.05 . Therefore it is not possible to generalize the results of the sample to the population with certainty.

Table 6. Testing of the Validity at the Level of the Population.

\begin{tabular}{|c|c|c|c|c|c|c|}
\hline \multicolumn{7}{|l|}{ ANOVA } \\
\hline & & Sum of Squares & $\mathrm{df}$ & Mean Square & $\mathrm{F}$ & Sig. \\
\hline \multirow{3}{*}{ Pre-test } & Between Groups & 10.203 & 2 & 5.102 & 0.753 & 0.474 \\
\hline & Within Groups & 589.452 & 87 & 6.775 & & \\
\hline & Total & 599.656 & 89 & & & \\
\hline \multirow{3}{*}{ Post-test } & Between Groups & 5.858 & 2 & 2.929 & 0.373 & 0.690 \\
\hline & Within Groups & 682.764 & 87 & 7.848 & & \\
\hline & Total & 688.622 & 89 & & & \\
\hline \multirow{3}{*}{ Difference } & Between Groups & 16.867 & 2 & 8.433 & 1.594 & 0.209 \\
\hline & Within Groups & 460.422 & 87 & 5.292 & & \\
\hline & Total & 477.289 & 89 & & & \\
\hline
\end{tabular}

\section{Discussion}

3D modeling presented an elective activity for the students as a technical extra-curricular activity. It can be seen that there were more male students than female ones, as technical activities are generally more interesting to male students.

The sample also contained relatively few left-hemispheric students, which can be explained by the fact that 3D modeling is an activity that attracts more students of the visual type. The latter are prone to using visual images in various activities. On the other hand, in the selfassessment questionnaire a relatively large number of students defined themselves as the inte- 
grative type, i.e. as students with a learning style that does not prefer activities typical of either the left-hemispheric or right-hemispheric type of students. In the classification of students into individual categories with regard to the hemisphericity of the brain there were smaller or greater deviations of one category against the other two. A tendency towards an individual learning style was sought. In addition to the used self-assessment questionnaire there are other methods to recognizing a specific student type. Thus the work of Barbara Meister Vitale (Meister Vitale, 2004) describes the following methods of ascertaining hemispheric dominance: observing the child (e.g. dreaminess, use of verbal or nonverbal communication, impulsiveness,...), tests of dominance (dominance of the eye, position of the hand, muscle test, eye movements, body symmetry,...) or the open questions method (e.g. a student imagines the singing of birds or the murmur of the sea and then points to the part of his/her head where these sounds are being heard).

Other research (Martin-Dorta, Saorin, Contero, 2008) has shown that 3D modeling has a positive impact on spatial ability. Spatial ability may also be influenced by the perceptual style of the student with regard to the receiving of information (visual, auditory, kinesthetic), or gender, which is influenced by the evolutionary aspect (Gardner 2010; Basham, 2006) or hormonal activity (Kolbl, Whishaw, 2003) or a combination of the genetic code and hormonal activity (Zaidi, 2010).

\section{Conclusions}

The results of the test show that the greatest difference can be found in the average of the points obtained among the left-hemispheric students, despite the fact that these students are better at verbal understanding and less at understanding spatial notions and relations. Such persons do, however, strive towards greater accuracy. Also possible is the explanation that this group of students had slightly worse spatial ability prior to the 3D modeling activity and that the activity itself enabled greater progress of this ability.

Contrary to expectations, students with a dominant right hemisphere demonstrated the least progress in spatial ability due to 3D modeling. This fact can be explained from the standpoint that these individuals had the best spatial ability prior to the start of the activity, but in comparison with the other two hemispheric types showed the smallest difference when comparing the results of Pre-test and Post-test.

\section{References}

Basham, K. L. (2006). The effects of 3-dimensional CADD modeling software on the development of spatial ability of ninth grade Technology Discovery students. Louisiana State University and Agricultural \& Mechanical College.

Demetriou, A., Raftopoulos, A. (2004). Cognitive Developmental Change. Cambridge: Cambridge University Press.

Entwistle, N. (1981). Styles of Learning and Teaching. An integrated Outline of Educational Psychology for Students, Teachers and Lecturers. New York: John Wiley \& Sons.

Gardner, H. (2010). Frames of Mind: The Theory of Multiple Intelligences. Ljubljana: Tangram.

Kolb, B., Whishaw, I. Q. (2003). Fundamentals of Human Neuropsychology, Fifth Edition. New York: Worth publishers.

Labinowicz, E. (2010). The Piaget Primer. Ljubljana: DZS.

Marentič Požarnik, B. (2000). Psychology of Learning and Instruction. Ljubljana: DZS.

Marentič Požarnik, B., Magajna, L., Peklaj, C. (1995). Challenge of Diversity. Nova Gorica: Educa.

Martin-Dorta, N., Luis Saorin, J., Contero, M. (2008). Development of a Fast Remedial Course to Improve the Spatial Abilities of Engineering Students. Journal of Engineering Education, 97 (4), $505-513$. 
Andrej ŠAFHALTER, Srečko GLODEŽ, Karin BAKRAČEVIČ VUKMAN. Spatial Ability, 3D Modeling and Styles of Thinking in Relation to Brain Hemisphere Dominance

PROBLEMS

OF EDUCATION

IN THE $21^{\text {st }}$ CENTURY

Volume 54, 2013

Meister Vitale, B. 2004. Unicorns Are Real: A Right-Brained Approach to Learning. Donji Vukojevac: Ostvarenje.

Newton, P., Bristoll, H. Spatial Ability, Practice Test 1. Psychometric Success.

Reynolds, C. R., Kaltsounis, B., Torrance, E. P. (1979). Children's Form of Your Style of Learning and Thinking: Preliminary Norms and Technical Data. The Gifted Child Quarterly, 23 (4), 757 767.

Zaidi, F. Z. 2010. Gender Differences in Human Brain: A Review. The Open Anatomy Journal, 2,37 55.

Advised by Renata Bilbokaite, University of Siauliai, Lithuania

Received: May 07, 2013

Accepted: June 13, 2013

Andrej Šafhalter

Professor, Primary School Anice Černejeve Makole, Makole 24, 2321 Makole, Slovenia.

E-mail: andrej.safhalter@os-makole.si

Website: http://www.os-makole.si

Srečko Glodež

PhD., Professor, University of Maribor, Faculty of Natural Sciences and Mathematics, Department of Technical Education, Koroška 160, 2000 Maribor, Slovenia.

E-mail: srecko.glodez@uni-mb.si

Website: http://tehnika.fnm.uni-mb.si

Karin Bakračevič Vukman

PhD., Professor, Department of Psychology, Faculty of Arts, University of Maribor, Koroska 160, 2000 Maribor, Slovenia.

E-mail: karin.bakracevic@um.si 